\title{
Progesterone and Brain Cancer
}

\author{
Rahim Ahmadi, Shams K*
}

\begin{abstract}
There are repots indicating that sex steroids play role in cancer development and treatment as well. We exerted laboratory experimental research to assess cytotoxic effects of progesterone on brain cancer cells (A172) in cell culture. A172 cells were exposed to $0.001,0.01,0.1,1$ and $10 \mathrm{mg} / \mathrm{ml}$ of progesterone solution. MTT assay was used to determine cytotoxic effects of the progesterone. Our results indicated that exposure to $0.1,1$ and $10 \mathrm{mg} / \mathrm{ml}$ of progesterone led to significant decrease in viability compared to control cells $(\mathrm{P}<0.05, \mathrm{p}<0.05$ and $\mathrm{P}<0.001$, respectively). According to our finding, high doses of progesterone have cytotoxic effects on brain tumor cells (A172 cell line) in cell culture.
\end{abstract}

Index Terms-Progesterone, A172, Viability.

\section{INTRODUCTION}

A brain tumor occurs when abnormal cells grow and develop within the brain[1]. There are two main types of tumors: malignant or cancerous tumors and benign tumors[1]. Cancerous tumors can be divided into primary tumors that start within the brain, and secondary tumors that have spread from somewhere else, known as brain metastasis tumors.[2] All types of brain tumors may produce symptoms that depending on the part of the brain involved this symptoms may include headache ,problem with vision and mental changes.[3] More specific problems may include difficulty in walking, speaking and sensation.[4] There are no known enviromental factors associated with brain tumors. mutations and deletions of so-called tumor suppressor genes, are thought to be the cause of some forms of brain tumor.[5] Secondary tumors of the brain are more common than primary ones, Primary brain tumors are a heterogeneous group of tumors which vary by the tissue of origin. The two most common types are gliomas and meningiomas.[6] The etiology of these tumors is mainly unknown. Aside from extremely rare genetic conditions, such as neurofibromatosis and tuberous sclerosis.[7],[8] the only unequivocally identified risk factor is exposure to ionizing radiation[9] A172 cell is a glioblastoma cell which is commonly used in research fields to investigate the effects of chemical agents on glioblastoma cells in cell culture. We exerted laboratory experimental research to assess cytotoxic effects of progesterone on brain cancer cells (A172) in cell culture.

\section{MATERIAL AND METHODS}

Different concentrations $(0.001,0.01,0.1,1$ and $10 \mathrm{mg} / \mathrm{ml})$ of progesterone were prepared and used in our study. A172

Rahim Ahmadi (PhD) is with the Department of Physiology, Faculty of Basic Sciences, Islamic Azad University, Hamedan Branch, Hamedan, Iran.

Kimiya Shams (*corresponding author) is with Department of Biotechnology, Faculty of Basic Sciences, Islamic Azad University of North Tehran, Tehran, Iran cells (brain cancer cell line) were purchased from National Cell Bank of Iran (Pasteur Institute, Tehran, Iran). Cells were grown and incubated in standard situation. Then, cells were sub-cultured into $75 \mathrm{~cm}^{2}$ flasks, 96 -well plates or 6-well plates. Cytotoxicity of different doses of the progesterone was assayed using MTT method. Analyses were conducted using the SPSS 20 and ANOVA.

\section{RESULTS}

Our results indicated that exposure to $0.1,1$ and $10 \mathrm{mg} / \mathrm{ml}$ of progesterone led to significant decrease in viability compared to control cells $(\mathrm{P}<0.05, \mathrm{p}<0.05$ and $\mathrm{P}<0.001$, respectively). (Figure I).

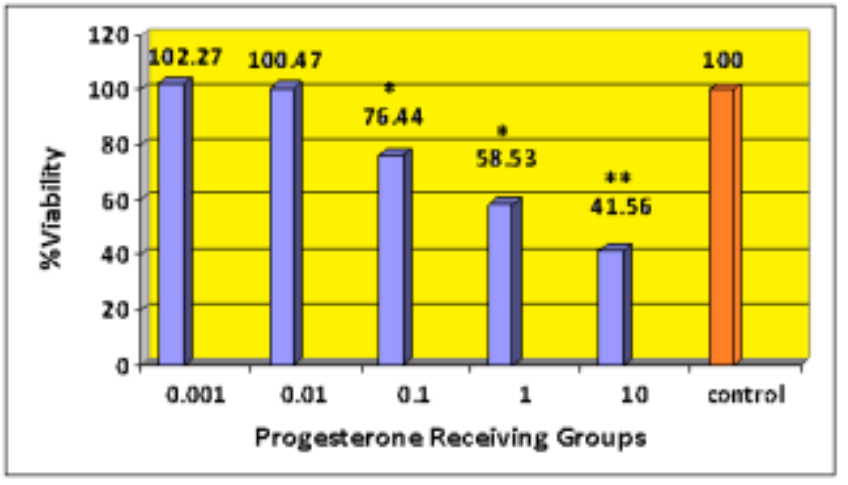

Figure I. Viability of A172 cells compared to control group. *and ** indicates significant difference compared to control group $(\mathrm{P}<0.05$ and $\mathrm{P}<0.001$, respectively).

\section{Discussion}

It has been suggested that female sex hormones influence the development and growth of brain tumors, particularly meningiomas. A higher female :male ratio in some types of nervous system malignancies, especially during the female reproductive years[10] and an observed growth stimulation during pregnancy and the luteal phase of menstruation[11] support this hypothesis. However, a higher incidence of glioma in men has been shown to be evident around the age of female menarche, reaching a maximum around the age of menopause and diminishing thereafter, suggesting that female hormones may have a protective effect. [12]

Hormone receptors are present in brain tumor tissue; progesterone receptors are present in approximately two thirds of meningiomas, estrogen receptors in one tenth, and androgen receptors in two thirds. [13] Primary brain tumors are a heterogeneous group of tumors which vary by the tissue of origin.[14] The etiology of these tumors is mainly unknown. Aside from extremely rare genetic conditions, such as neurofibromatosis and tuberous sclerosis, [15] the only unequivocally identified risk factor is exposure to ionizing radiation. [16] The hormone progesterone could become part of 
therapy against the most aggressive form of brain cancer. High concentrations of progesterone kill glioblastoma cells and inhibit tumor growth when the tumors are implanted in mice, researchers have found.[17] Sex differences in glioma and meningioma incidence suggest that hormones could influence the development of these tumors; the incidence of meningiomas is about 2 times greater in women than in men, whereas the incidence of gliomas is around 1.5 times greater in men than in women. Increased growth rates of meningiomas have been observed during pregnancy, and a strong association exists between breast cancer and meningioma[18][19] and a strong association exists between breast cancer and meningioma . Taken together, these observations support a role for female hormones (in particular progesterone) in the etiology of nervous system cancers [20] including brain cancers. We have shown cytotoxic effects of progesterone on glioblastoma cells in cell culture. Further researches are required to show the exact role played by progesterone in development of brain tumors in cellular and molecular level.

\section{CONCLUSION}

According to our finding, high doses of progesterone have cytotoxic effects on brain cancer cells in cell culture.

\section{ACKNOWLEDGMENT}

We appreciate all who helped us to exert this study.

\section{REFERENCES}

[1] "General Information About Adult Brain Tumors". NCI. 2014-04-14. Retrieved 8 June 2014.

[2] Inskip PD, Linet MS, Heineman EF. Etiology of brain tumors in adults. Epidemiol Rev 1995;17:382-414.

[3] Longo, Dan L (2012). "369 Seizures and Epilepsy". Harrison's principles of internal medicine (18th ed.). McGraw-Hill. p. 3258. ISBN 978-0-07-174887-2

[4] World Cancer Report 2014. World Health Organization. 2014. pp. Chapter 5.16. ISBN 9283204298

[5] Kleihues P, Ohgaki H, Eibl RH, Reichel MB, Mariani L, Gehring M, Petersen I, Höll T, von Deimling A, Wiestler OD, Schwab M (1994). "Type and frequency of p53 mutations in tumors of the nervous system and its coverings". Molecular Neuro-oncology and Its Impact on the Clinical Management of Brain Tumors. Recent results in cancer research. 135. Springer. pp. 25-31. ISBN 3540573518 https://doi.org/10.1007/978-3-642-85039-4_4

[6] Kleihues P, Cavenee WK. World Health Organization classification of tumours. Pathology and genetics: tumours of the nervous system. 2nd ed. Lyon, France: IARC Press, 2000.

[7] Inskip PD, Linet MS, Heineman EF. Etiology of brain tumors in adults. Epidemiol Rev 1995;17:382-414.

[8] Wrensch M, Minn Y, Chew T, et al. Epidemiology of primary brain tumors: current concepts and review of the literature. Neuro-Oncol 2002;4:278-99. https://doi.org/10.1093/neuonc/4.4.278

[9] Ron E, Modan B, Boice JD Jr, et al. Tumors of the brain and nervous system after radiotherapy in childhood. N Engl J Med 1988;319:1033-9 https://doi.org/10.1056/NEJM198810203191601

[10] Helseth A. Incidence and survival of intracranial meningioma patients in Norway 1963-1992. Neuroepidemiology 1997;16:53-9 https://doi.org/10.1159/000109671

[11] Michelsen JJ, New PF. Brain tumour and pregnancy. J Neurol Neurosurg Psychiatry 1969;32:305-7. https://doi.org/10.1136/jnnp.32.4.305

[12] Schoenberg BS, Christine BW, Whisnant JP. Nervous system neoplasms and primary malignancies of other sites. The unique association between meningiomas and breast cancer. Neurology 1975;25:705-12 https://doi.org/10.1212/WNL.25.8.705
[13] Blankenstein MA, Verheijen FM, Jacobs JM, et al. Occurrence, regulation, and significance of progesterone receptors in human meningioma. Steroids 2000;65:795-800. https://doi.org/10.1016/S0039-128X(00)00193-8

[14] Kleihues P, Cavenee WK. World Health Organization classification of tumours. Pathology and genetics: tumours of the nervous system. 2nd ed. Lyon, France: IARC Press, 2000

[15] Inskip PD, Linet MS, Heineman EF. Etiology of brain tumors in adults. Epidemiol Rev 1995; 17:382-414.

[16] Preston DL, Ron E, Yonehara S, et al. Tumors of the nervous system and pituitary gland associated with atomic bomb radiation exposure. J Natl Cancer Inst 2002;94:1555-63. https://doi.org/10.1093/jnci/94.20.1555

[17] Beral V, Million Women Study Collaborators. Breast cancer and hormone-replacement therapy in the Million Women Study. Lancet. 2003;362:419-427 https://doi.org/10.1016/S0140-6736(03)14065-2

[18] Wrensch M, Jenkins RB, Chang JS, et al. Variants in the CDKN2B and RTEL1 regions are associated with high-grade glioma susceptibility. Nat Genet 2009;41:905-8. https://doi.org/10.1038/ng.408

[19] CBTRUS. Statistical Report: Primary Brain Tumors in the United States, 1998-2002. Central Brain Tumor Registry of the United States; 2005.

[20] Koper JW, Lamberts SW. Meningiomas, epidermal growth factor and progesterone. Hum Reprod 1994;9 Suppl 1:190-4 https://doi.org/10.1093/humrep/9.suppl_1.190 